\title{
PASTEURELLA CANIS CAUSING COMMUNITY ACQUIRED LRTI: FOOTSTEP OF A NOVEL DEMON
}

Jayashree Konar ${ }^{1}$, Sayantan Banerjee ${ }^{2}$, Suranjan Pal ${ }^{3}$, Piyali Datta ${ }^{4}$, Chinmoy Sahu ${ }^{5}$, Amrita Naha6

\section{HOW TO CITE THIS ARTICLE:}

Jayashree Konar, Sayantan Banerjee, Suranjan Pal, Piyali Datta, Chinmoy Sahu, Amrita Naha. "Pasteurella Canis Causing Community Acquired LRTI: Footstep of a Novel Demon". Journal of Evolution of Medical and Dental Sciences 2015; Vol. 4, Issue 14, February 16; Page: 2408-2412, DOI: 10. 14260/jemds/2015/347

ABSTRACT: Pasteurella canis is a Gram-negative, nonmotile, coccobacillus belonging to the family Pasteurellaceae, erstwhile known to be penicillin-sensitive. It is a known causative organism for zoonotic infections especially skin and soft tissue infections after animal bite. It is known to cause respiratory tract infection among immunocompromised patients. Here we present a case of community-acquired lower respiratory tract infection (LRTI) in an apparently immunocompetent middle aged female patient caused by multidrugresistant (MDR) Pasteurella canis biovar2. We suggest the organism to be included in differential diagnosis in such cases.

KEYWORDS: Pasteurella canis biovar-2, LRTI, MDR.

INTRODUCTION: Pasteurella canis is a Gram-negative, nonmotile, penicillin-sensitive coccobacillus belonging to the Pasteurellaceae family.(1) "Micrococcus gallicidus" was the first scientific name used for these bacteria. ${ }^{(2,3)}$ For a short period of time, the bacteria were unofficially placed in different genera, such as Octopsis, Coccobacillus, and Eucystia. In 1887, genus "Pasteurella" was proposed to honor Louis Pasteur for his critical discoveries in the field of Microbiology.(1) P. canis includes two biotypes: biovar 1 is originated from canine, whereas biovar(2) is originated from bovine.(1)

Bacteria from this family cause zoonotic infections in humans. These infections manifest themselves as skin or soft tissue infections after an animal bite. It has been known to cause serious disease in immunocompromised patients. $(4,5)$

There are few case reports of lower respiratory tract infection in COPD patients caused by canine associated Pasteurella in literature but unfortunately there is lack of correspondences among Indian workers regarding this topic.(6)

Present case report of Lower respiratory tract infection caused by multi drug resistant Pasteurella canis, thus aims at drawing attention of medical fraternity to give enough weightage to this unusual human pathogen.

BRIEF HISTORY OF THE CASE: A 56 year old female patient was admitted with shortness of breath for 15 days. She was not a known case of diabetes mellitus or hypertension. 20 years ago, she suffered from pulmonary Tuberculosis which was treated with full course of antitubercular drugs. At the end of first line of Anti Tubercular treatment schedule, the patient was documented as a cured one. There was no history of canine exposure.

She was alert, conscious and co-operative at the time of examination. Mild anaemia was there. No cyanosis or clubbing was revealed during general examination. Respiratory rate was 30/minute and regular. Bilateral crepitations were present. No abnormality was found in other systems.

She was diagnosed to be a patient of Bronchiectasis diagnosed by Pulmonary HRCT. There was no pleural thickening. 


\section{CASE REPORT}

MATERIALS \& METHODS: Sputum samples were collected on two consecutive days.

Direct smears were stained with gram stain and Ziehl-Neelsen stain. Inoculation on MacConkey's agar plate and Blood agar plate was performed followed by overnight aerobic incubation at $37^{\circ} \mathrm{C}$. Discrete colonies were selected for identification and anti-microbial susceptibility testing by Kirby Bauer Disk Diffusion test. For phenotypic identification, VITEK 2 Compact Advanced Expert System (AES) was used.

RESULT: Microscopy of direct smears revealed that Pus cells were plenty ( $\geq 25$ per low power field) and few epithelial cells ( $\leq 10$ per low power field) were present. No acid fast bacillus was found.

After overnight incubation both the samples yielded pure growth of no lactose fermenting, mucoid, round colonies. It was nonhemolytic (Fig. $1 \& 2$ ). No characteristic odour or pigment could be identified. When Gram stain was performed, it was found to be Gram-negative coccobacillus that also took bipolar staining (Fig. 3). The microorganism was a nonmotile one. VITEK 2 Compact AES system identified it as Pasteurella canis with good confidence level (91\%) (Fig. 4). The isolated bacteria was Indole test negative, so it was identified as biovar.(2) (Fig. 5).
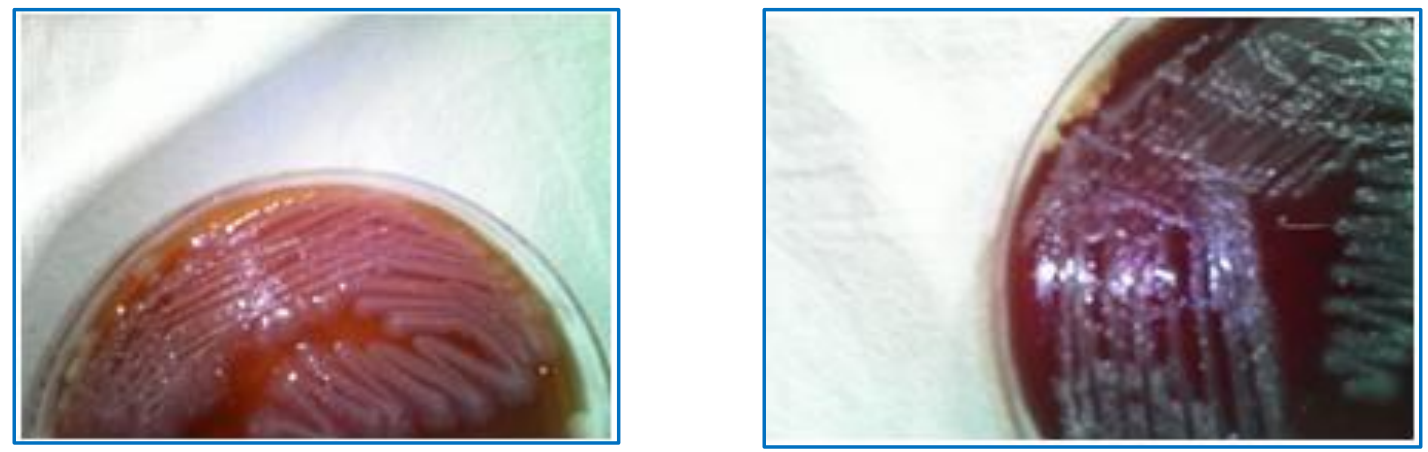

Fig. 1 \& 2: Colony of Pasteurella canis on Mac-conkey's agar plate

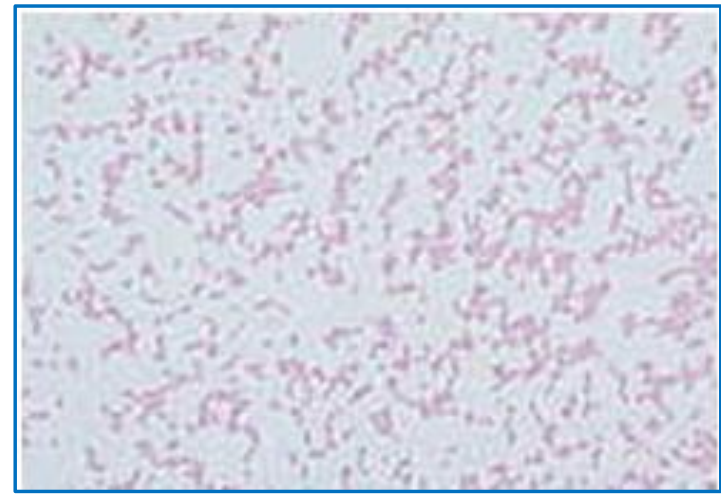

Fig. 3: Gram negative occobacilli. (1000X) 


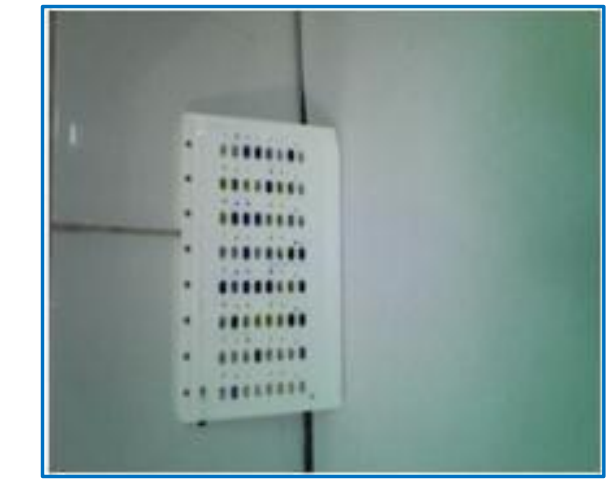

Fig. 4: Biochemical analysis card of Vitek 2 Compact (AES) (1000X)

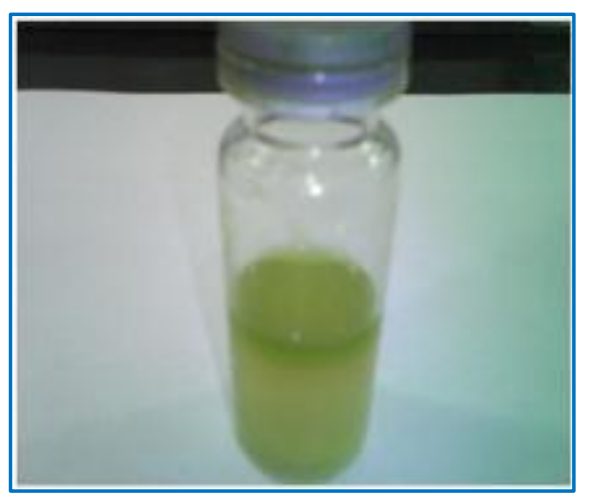

Fig. 5: Negative Indole test implies that Tryptophanase was not produced by the Isolate

The isolate was sensitive only to Colistin, Polymyxin -B and Tigecycline. It was resistant to all other antibiotics such as Amikacin, Gentamicin, Cefepime, Pipericillin- Tazobactam, CefoperazoneSulbactam, Meropenem, Imipenem, Cotrimoxazole and Ciprofloxacin. The finding was confirmed by similar results in all the tests for both the samples.

The patient was treated with intravenous Colistin $1.5 \mathrm{mg} / \mathrm{kg}$ and clinically recovered after 3 days. Sputum sampling was repeated on the $4^{\text {th }}$ day in which no pathogenic bacteria were grown.

DISCUSSION: Soft tissue infections caused by Pasteurella canis were reported by several workers. However, Pasteurella multocida is more commonly associated with systemic involvements including respiratory infections. $(7,8,9,10,11,12)$

This present case report is unique in several aspects.

First, Community acquired lower respiratory tract infection caused by P. canis in a COPD patient without any history of canine exposure. The mystery was solved when the history of bovine exposure was revealed and the isolate was identified as Pasteurella canis biovar.(2)

Second, the organism was found to be sensitive to Colistin, Polymyxin-B and Tigecycline and resistant to all of the first line and second line drugs recommended by CLSI guideline 2014 whereas Pasteurella canis isolated by Kim Allison and Jill E. Claridge were sensitive to Penicillin.(6)

The above said case suggests that health care personnels to remain always vigilant to identify the respiratory pathogen in patients with COPD because Pasteurella canis has its all potential to become a multidrug resistant emerging threat to mankind if overlooked by medical fraternity.

\section{REFERENCES:}

1. Mutters, R; P., Pohl, S., Frederiksen, W., and Mannheim, W. (1985). "Reclassification of the Genus Pasteurella Trevisan 1887 on the Basis of Deoxyribonucleic Acid Homology, with Proposals for the New Species Pasteurella dagmatis, Pasteurella canis, Pasteurella stomatis, Pasteurella anatis, and Pasteurella langaa.". International Journal of Systematic Bacteriology: 309-322.

2. Illinois Industrial University, Board of Trustees (1882). Annual Report of the Board of Trustees of the Illinois Industrial University.

3. Burrill, T. J. "New species of Micrococcus (bacteria)". Am. Nat. 17: 319-320. 


\section{CASE REPORT}

4. Hara, H; Ochiai, T.; Morishima, T.; Arashima, Y.; Kumasaka, K.; Kawano, K. (2002). "Pasteurella canis osteomyelitis and cutaneous abscess after a domestic dog bite". Journal of the American Academy of Dermatology. 46 (5 Supplement): S151-S152.

5. Albert, T.J.; Stevens, D.L. (2010). "The first case of Pasteurella canis bacteremia: a cirrhotic patient with an open leg wound." Infection 38 (6): 483-485.

6. Kim Allison and Jill E. ClarridgeIII. Long-Term Respiratory Tract Infection with Canine "Associated Pasteurella dagmatis and Neisseria canis in a Patient with Chronic Bronchiectasis". J. Clin. Microbiol. 2005, 43 (8): 4272-4274.

7. Heydemann J, Heydemann JS, Antony S. Acute infection of a total knee arthroplasty caused by Pasteurella multocida: a case report and a comprehensive review of the literature in the last 10 years. Int J Infect Dis. Sep 2010; 14 Suppl 3: e242-5.

8. Oehler RL, Velez AP, Mizrachi M, Lamarche J, Gompf S. Bite-related and septic syndromes caused by cats and dogs. Lancet Infect Dis. Jul 2009; 9 (7): 439-47.

9. Harris PJ, Osswald MB. Pasteurella multocida epiglottitis: A review and report of a new case with associated chronic lymphocytic leukemia. Ear Nose Throat J. Dec 2010; 89 (12): E4.

10. Dryden MS, Dalgliesh D. Pasteurella multocida from a dog causing Ludwig's angina. Lancet. Jan 13 1996; 347 (8994): 123.

11. Goussard P, Gie RP, Steyn F, Rossouw GJ, Kling S. Pasteurella multocida lung and liver abscess in an immune-competent child. Pediatr Pulmonol. Mar 2006; 41 (3): 275-8.

12. Kagihara JM, Brahmbhatt NM, Paladino J. A fatal pasteurella empyema. Lancet. Aug 2 2014; 384 (9941): 468. 


\section{AUTHORS: \\ 1. Jayashree Konar \\ 2. Sayantan Banerjee \\ 3. Suranjan Pal \\ 4. Piyali Datta \\ 5. Chinmoy Sahu \\ 6. Amrita Naha}

\section{PARTICULARS OF CONTRIBUTORS:}

1. Senior Resident, Department of Microbiology, ESI-PGIMSR, ESIC Medical College and ESIC Hospital \& ODC (EZ), Joka, Kolkata.

2. Assistant Professor, Department of Microbiology, ESI-PGIMSR, ESIC Medical College and ESIC Hospital \& ODC (EZ), Joka, Kolkata.

3. Senior Resident, Department of Microbiology, ESI-PGIMSR, ESIC Medical College and ESIC Hospital \& ODC (EZ), Joka, Kolkata.

4. Tutor, Department of Microbiology, ESIPGIMSR, ESIC Medical College and ESIC Hospital \& ODC (EZ), Joka, Kolkata.

FINANCIAL OR OTHER COMPETING INTERESTS: None
5. HOD, Department, Department of Microbiology, ESI-PGIMSR, ESIC Medical College and ESIC Hospital \& ODC (EZ), Joka, Kolkata.

6. Tutor, Department of Microbiology, ESIPGIMSR, ESIC Medical College and ESIC Hospital \& ODC (EZ), Joka, Kolkata.

\section{NAME ADDRESS EMAIL ID OF THE CORRESPONDING AUTHOR:}

Dr. Chinmoy Sahu,

Head of the Department, Department of Microbiology,

Room No. 226, $1^{\text {st }}$ Floor, ESI-PGIMSR, ESIC Medical College and, ESIC Hospital \& ODC (EZ), Diamond Harbour Road, Joka-700104, Kolkata, West Bengal, India.

E-mail: sahu.chinmoy@gmail.com

Date of Submission: 23/01/2015.

Date of Peer Review: 24/01/2015.

Date of Acceptance: 07/02/2015.

Date of Publishing: 16/02/2015. 